\title{
Residents' knowledge of waste reduction, reusing and recycling in Makurdi metropolis, Nigeria
}

\author{
M. S. Awopetu ${ }^{1}$, A. O. Coker $^{2}$, R. G. Awopetu ${ }^{3}$, S. O. Awopetu ${ }^{4}$, \\ A. A. Ajonye A $^{3}$ O. W. Awopetu ${ }^{5}$ \\ ${ }^{I}$ Nigeria Security and Civil Defence Corps, Benue State Command, \\ Makurdi, Nigeria \\ ${ }^{2}$ Department of Civil Engineering, University of Ibadan, Nigeria \\ ${ }^{3}$ Department of Psychology, Benue State University, Makurdi, Nigeria \\ ${ }^{4}$ Department of Environmental, Civil and Geomatic Engineering, \\ University College, London, UK \\ ${ }^{5}$ Department of Civil Engineering, University of East London, UK
}

\begin{abstract}
This study focused on residents' knowledge of solid waste reduction, reuse and recycling (3Rs) as sustainable solid waste management (SSWM) options in Makurdi metropolis, a rapidly growing urban city in the North central (middle belt region) of Nigeria. The area surveyed covered low (zone I), medium (zone II) and high- density (zone III). Data used for this study were collected by the use of literature search, administration questionnaire $(n=560)$, formal and informal interviews, and observational checklists. Analyses of the data revealed that $>72 \%$ of the respondents in the three environmental zones are aware of the fact that solid waste can be reused, reduced and recycled. The trouble is, merely knowing something is not, by itself, sufficient to generate beneficial outcomes. There is a need for the residents to be educated or informed on how solid waste can be reused and reduced from source. The Government needs to put uninterrupted electricity supply in place as a basic ingredient for small medium and large scale industry. The market for recyclable products should also be strengthened.
\end{abstract}

Keywords: solid waste management, waste minimization, reduction, reuse, recycling, practices, Nigeria. 


\section{Introduction}

Solid waste could be regarded as "resources in the wrong place" (Adewumi et al. [1]). In nature, there is essentially no solid waste because the wastes of one organism become nutrients for other organisms. Man existence will always produce some solid wastes either directly and or indirectly in creating the goods and services we use. Much of solid waste we produce represents an unnecessary waste of the earth's precious resources.

Wherever people exist, waste disposal is likely to constitute a problem. From prehistory through the present day, the favoured means of disposal was simply to dump solid wastes outside of the city or village limits. Frequently these dumps were in wetlands adjacent to a river or lake. To minimize volume of the waste, the dump was often burned. Unfortunately, the above scenario depicts the situation in Makurdi metropolis in particular and Nigeria in general. As better solid waste management/disposal technologies were developed and as values changed, more emphasis was placed on the environment and quality of life. Dumping and open burning of wastes is no longer an acceptable practice from an environmental and health perspective. In developed countries, the technology of waste disposal has evolved during some decades in the past. Many developed countries have widely accepted that solid waste management options should be selected based on a waste management hierarchy of waste reduction, reuse, recycle, composting, incineration and land filling.

The sheer magnitude of the solid waste problem in Makurdi metropolis, Nigeria is hard to comprehend. The public waste bins are either not available or grossly inadequate; the amount of trash that accumulates in a matter of hours is more than what waste collectors can haul in a day. The garbage dumps are located in the side of the highway at the fringe of cities and slums. Trash often spread into the road, blocking traffic.

The problem of solid waste in every city in Nigeria including Makurdi metropolis is multifaceted. These ranges from the government's lack of clear formulated policies aims at coordinating and monitoring the relationship between environmental management and sustainable development. Secondly, it is estimated that nearly $10 \%$ of the population live below national poverty line (World Bank [2]). As a result of the enormity of the problem of solid waste in Nigeria, several attempts have been made by the government and researchers to find a sustainable solution to the solid waste menace.

To lessen the burden of solid waste management on government, individual and environment, there is a need to critically look into waste reduction, reuse and recycling as feasible options in tackling the issue of solid waste management in Makurdi metropolis and Nigeria in general. Hence the study was predicated on the following objectives: (1) to assess the residents' knowledge of waste reduction, reusing and recycling in Makurdi metropolis; (2) to determine the feasibility of reducing, reusing and recycling solid waste in Makurdi metropolis and; (3) to recommend how waste reduction, reusing and recycling can be achieved in Makurdi metropolis. 


\section{The study area}

The study area, Makurdi metropolis is the capital city of Benue State in the middle belt region (north-central part) of Nigeria. According to Wikipedia [3], Benue has a Gross Domestic Product of \$1.592. It is a typical example of a Nigeria city with mixed population characterized with diverse cultural background. Prominent among the ethnic group in Makurdi metropolis are the Tivs, Idomas, Igedes, Hausas, Yorubas, and Ibos etc. According to the National Population Census Report [4], the population of Makurdi was put at 297,398. It has an estimated area of 41,035 $\mathrm{km}^{2}$. Makurdi Local Government Area which essentially traverses the Benue State Capital is the most densely populated Local Government Area in Benue State with an average of 257 persons per $\mathrm{km}^{2}$. It lies between longitude $6^{\circ} 45^{\prime}$ and $8^{\circ} 15^{\prime} \mathrm{E}$ and latitude $7^{\circ} 30^{\prime}$ and $9^{\circ} 45^{\prime} \mathrm{N}$.

The city experiences $7-8$ rainy months with the highest rainfall and rainy days in September. Monthly minimum temperature fluctuates between 17.5$18.5^{\circ} \mathrm{C}$ in December and January and $25.7^{\circ} \mathrm{C}$ in April. Relative humidity at 0900 hours is high in July with $78.5 \%$. Highest relative humidity at 1500 hours is $70.6 \%$ in the month of August. The mean daily sunshine period is 4.9 hours in July and 7.2 hours in November. The relief flanking the flood plains around Makurdi is between $76 \mathrm{~m}$ and $82 \mathrm{~m}$ above the sea level. Absence of outcrops of rocks allow for free flow of the rivers without rapids thereby revealing shallow depths of large volume of sand deposit.

\section{Research methodology}

In other to obtain the required data and information, the study which was conducted between July and September 2009, employed a methodology that include literature search, questionnaire administration, formal and informal interviews, and use of observational checklists. For the collection of data, the study area was partitioned into three zones (table 1).

Table 1: $\quad$ Environmental zones delineated in Makurdi.

\begin{tabular}{|l|l|l|l|l|}
\hline Zone & Name of the area & Area $\left(\mathrm{km}^{2}\right)$ & Population $/ \mathrm{km}^{2}$ & $\begin{array}{l}\text { Density } \\
\text { Classification }\end{array}$ \\
\hline I & Madikpo/Wadata & 9.38 & 4.1 & High \\
\hline II & Lobi/Wadata & 15.78 & 536.0 & Medium \\
\hline III & $\begin{array}{l}\text { Old Government } \\
\text { Reserved Area }\end{array}$ & 15.88 & 88.0 & Low \\
\hline
\end{tabular}

The zones tend to exhibit different characteristics in solid waste generation, awareness, attitude and participation in solid waste management. The population density/land use intensity criteria were used to delineate the study area into zones I, II, III (figure 1). The study area selected in each zone was based on the following characteristics: (a) Solid waste management has been clearly identified as a serious problem; (b) Home of people with different ethnic backgrounds and; (c) Relatively planned area for ease of administration of questionnaires. The 
questionnaire $(\mathrm{n}=560)$ was then distributed across the three zones (in compliance with the University of Ibadan ethics code). Upon return of the data $(\mathrm{n}=545 ; 97.3 \%$ response), descriptive statistical analysis was applied.

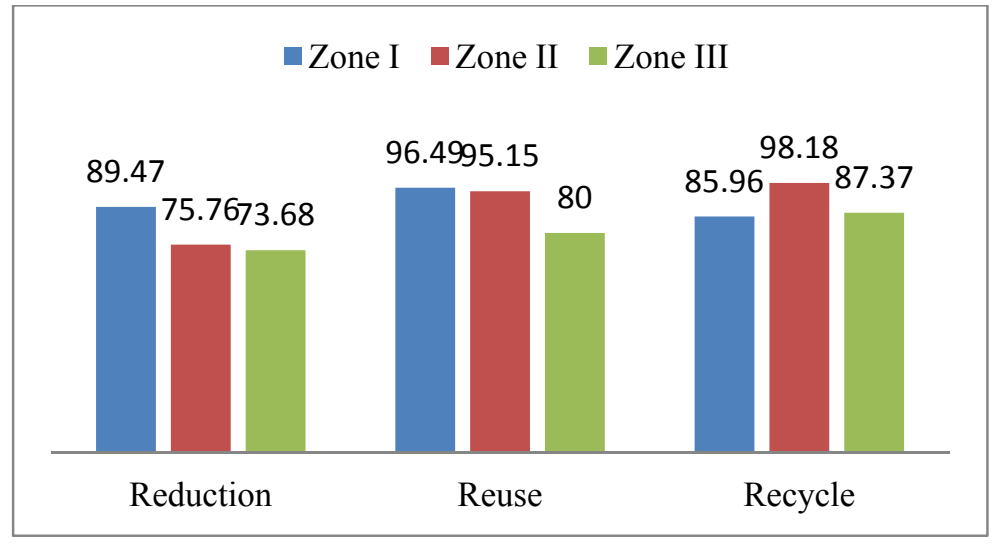

Figure 1: Residents' awareness of solid waste reduction, reusing and recycling across the three environmental zones in Makurdi metropolis.

\section{Result and discussions}

Compositional analysis of solid waste in the Makurdi Metropolitan area (Table 4) indicated a high percentage of waste throughout all the zones is putrescible $(57.5,53.7$ and $36.4 \%$ of solid waste composition in Zone I, Zone II and Zone III, respectively). The study reveals a very high degree of awareness of the importance of solid waste reduction in the fight against the problems of waste management across the study area (Tables 2 and 3). Analysis of the data collected shows a little variation in the residents' knowledge of waste reduction, reuse and recycling. More than $65 \%$ of the residents in the three environmental zones (Fig. 1) agreed that solid wastes can be reduced, reused and recycled.

Table 2: Respondents' knowledge of waste reduction, reuse and recycling $(\mathrm{n}=285)$.

\begin{tabular}{|l|l|l|l|l|}
\hline Statement & Respondent & Zone I & Zone II & Zone III \\
\cline { 3 - 5 } & & Frequency n (\%) & Frequency n (\%) & Frequency n (\%) \\
\hline Waste can be & Agree & $255(89.47)$ & $125(75.76)$ & $70(73.68)$ \\
reduced from the & Disagree & $30(10.53)$ & $40(24.24)$ & $25(26.32)$ \\
source & Total & $285(100)$ & $165(100)$ & $95(100)$ \\
\hline Waste can be & Agree & $275(96.49)$ & $157(95.15)$ & $76(80)$ \\
reused & Disagree & $10(3.51)$ & $08(4.85)$ & $19(20)$ \\
& Total & $285(100)$ & $165(100)$ & $95(100)$ \\
\hline Waste can be & Agree & $245(85.96)$ & $162(98.18)$ & $83(87.37)$ \\
recycled & Disagree & $40(14.04)$ & $03(01.82)$ & $12(12.63)$ \\
& Total & $285(100)$ & $165(100)$ & $95(100)$ \\
\hline
\end{tabular}


Table 3: $\quad$ Analysis of variance (ANOVA) of differences in the three zones.

\begin{tabular}{|c|c|c|c|c|c|c|c|c|}
\hline Statement & $\mathrm{n}$ & Mean & $\begin{array}{c}\text { Standard } \\
\text { Deviation }\end{array}$ & $\begin{array}{l}\text { Sum of } \\
\text { Squares }\end{array}$ & $\mathrm{df}$ & $\begin{array}{l}\text { Mean } \\
\text { Square }\end{array}$ & $\mathrm{F}$ & Significance \\
\hline \multirow{3}{*}{$\begin{array}{l}\text { Waste can } \\
\text { be reduced } \\
\text { from the } \\
\text { source }\end{array}$} & ${ }^{+} 391$ & 7.532 & 4.288 & \#8.988 & 1 & 8.988 & 0.558 & $0.055(\mathrm{NS})$ \\
\hline & ${ }^{++} 154$ & 7.247 & 3.202 & ${ }^{\# \#} 8739.974$ & 543 & 16.096 & & \\
\hline & \#\#\#545 & 7.451 & 4.010 & \#\#\#8748.961 & 544 & & & \\
\hline \multirow{3}{*}{$\begin{array}{l}\text { Waste can } \\
\text { be reused }\end{array}$} & ${ }^{+} 391$ & 5.361 & 1.000 & ${ }^{\# 1} 1.432$ & 1 & 1.432 & 1.312 & $0.023^{*}$ \\
\hline & ${ }^{++} 154$ & 5.247 & 1.151 & \#\#592.777 & 543 & 1.092 & & \\
\hline & \#\#\#545 & 5.328 & 1.045 & \#\#\#594.209 & 544 & & & \\
\hline \multirow{3}{*}{$\begin{array}{l}\text { Waste can } \\
\text { be } \\
\text { recycled }\end{array}$} & 391 & 6.056 & 1.180 & ${ }^{\# 1.002}$ & 1 & 1.002 & 0.733 & $0.039^{*}$ \\
\hline & ${ }^{++} 154$ & 5.961 & 1.427 & \#\#\#2.528 & 543 & 1.367 & & \\
\hline & $\#$ \#\#\# & 6.029 & 1.169 & $\#^{\# \#} 743.530$ & 544 & & & \\
\hline
\end{tabular}

*Significant at $\mathrm{P}<0.05, \mathrm{NS}=$ Not significant.

${ }^{+}$Low income (mean monthly income of $\left.\$ 100\right)$.

${ }^{++}$High income (mean monthly income of \$500).

"Between group.

\#\#ithin group.

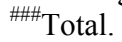

Table 4: Typical composition of solid waste in Makurdi urban area by generation.

\begin{tabular}{|c|c|c|c|c|c|c|c|c|}
\hline $\begin{array}{l}\text { Waste } \\
\text { source }\end{array}$ & \multicolumn{9}{|c|}{ Waste category } \\
& \multicolumn{9}{|c|}{} \\
\cline { 2 - 10 } & Putresceables $^{\mathrm{a}}$ & $\begin{array}{c}\text { Plastic/ } \\
\text { cellophane }\end{array}$ & Paper & Metals & Glass & Textile & $\begin{array}{c}\text { Fines } \\
\mathrm{c}\end{array}$ & Miscellaneous $^{\mathrm{d}}$ \\
\hline LoDA & 57.5 & 6.10 & 4.30 & 2.50 & 2.30 & 2.90 & 21.0 & 3.40 \\
\hline MeDA & 53.7 & 7.10 & 4.10 & 2.01 & 1.70 & 2.40 & 27.1 & 1.70 \\
\hline HiDA & 36.4 & 8.04 & 2.59 & 1.75 & 0.86 & 3.67 & 41.0 & 5.73 \\
\hline COMM & 27.9 & 10.2 & 10.9 & 3.40 & 6.90 & 1.20 & 36.4 & 3.10 \\
\hline INS & 44.8 & 5.90 & 8.90 & 0.90 & 1.20 & 0.30 & 36.4 & 3.10 \\
\hline SMI & 23.4 & 7.01 & 2.10 & 0.70 & 0.10 & 6.10 & 31.7 & 28.9 \\
\hline MART & 36.1 & 6.86 & 3.20 & 1.10 & 0.10 & 1.90 & 48.7 & 2.01 \\
\hline
\end{tabular}

Source: Sha'Ato et al. [5].

LoDA = low density area; MeDA = medium density area; HiDA = high density area; COMM $=$ commercial premises; INS $=$ institutional premises; SMIs $=$ small $/$ medium scale industry; MART $=$ Wadata market.

${ }^{a}$ Putresceables includes food remnants, fresh and decaying leaves, vegetations, etc;

${ }^{b}$ Metals - mostly cans and bottle caps; few ferrous metal and aluminium items;

cIncludes ash, dust and sand;

${ }^{\mathrm{d}}$ Other includes wood, stones and pebbles, discarded shoes and other footwear, wood shavings. (from carpenter's shop); Styrofoam, snail shells, discarded dry cells, etc.

\subsection{Solid waste reduction}

Overall, $>73 \%$ of the respondents were aware of the great dividend that could be realised from effective cutback in the production of waste. The trouble is, merely knowing something is not, by itself, sufficient to generate beneficial outcomes. 
The continuing exponential growth of solid waste generation in the study areas suggests that the widespread knowledge of the need to cut back on waste production is hardly producing practical beneficial effects. Knowledge must be backed by willingness and ability to act upon it.

It should be noted that we can deal with the waste we create in two ways: waste management or waste reduction. Waste management is a high-waste approach that views waste as a mostly unavoidable product of economic growth. It attempts to manage the waste that results from economic growth in ways that reduce environmental harm, mostly by mixing and often crushing wastes together and then burying them, burning them, or shipping them to another location. In effect, it commingles waste and then transfers them from one environment to another.

Waste reduction on the other hand is a low-waste approach that recognizes there is no "away." It mimics nature by viewing solid waste as potential resources that we should be reusing, recycling or composting. Waste reduction is the most preferred solution because it tackles the problem of waste production front end before it occurs rather than at the back end after the wastes have already been produced. Waste reduction at source should be vigorously pursued (Sangodoyin and Coker [6]). It also saves matter and energy resources, reduces pollution (including emissions of greenhouse gases), helps protect biodiversity, and saves money.

\subsection{Solid waste reuse}

Waste reuse involves cleaning and using materials over and over, thereby extending the typical life span of a product. Reusing items is a way to reduce waste at the source because it delays or prevents the entry of reused items into the waste collection and disposal system. It was found out that $96.49 \%, 95.15 \%$ and $80 \%$ of respondents in zone I, zone II and zone III respectively knew and thereby agreed that solid waste can be reused. In spite of the fact that residents know that some kind of solid waste can still be reused, it is disheartening to note that often than not, solid wastes are discarded without consideration for reuse in the high income earners located in zone III.

Locally within the Makurdi metropolis, form of reuse include salvaging automobile parts from old cars, salvaging, bricks, doors, fine woodworks and other items from old houses and buildings. Waste scavengers move from one house to the other practicing trade-by-barter by exchanging different types and sizes of brand new plastic/rubber containers with equivalent quantity of old dresses. The old dresses are no longer useful to the owners but are still useful to the waste buyer who after collecting the dresses will dry-clean and sell them to the poor.

It is pertinent to note that in developed countries, the societies have increasingly substituted throwaway tissues for reusable hand kerchiefs; disposable paper towels and napkins for reusable cloth ones; throwaway beverage containers for refillable ones. Whereas in Nigeria, the reusable baby napkins are being replaced by disposable pampers; all the bottled water and sachet water are disposable; all the yoghourt available in Nigeria market are 
packaged in disposable containers; beverages in disposable containers are increasingly popular in Nigeria with little or no attention to it economic and environmental disadvantage.

Reuse is thriving in most developing countries but can pose a health hazard for the poor. About $80 \%$ of the United States' e-waste, including discarded computers and cell phones, are shipped to China, India, and Pakistan, and other countries where labour is cheap and environmental regulations are weak (Miller [7]). For workers in these countries, many of their children are engaged in dismantling the products to recover reusable parts and are thus exposed to toxic metals such as lead, mercury, and cadmium. Nigeria electronic market is flooded with e-waste from European and American countries. It is stating the obvious to say that all electronics that are available in brand new model are also available in fairly used versions. Apart from the fact that the fairly used are economically cheaper, they are believed by the users to be more durable.

In cities and towns such as Makurdi metropolis, large number of people, many of them children, eke out a living by scavenging for materials they can sell for reuse or recycling from open city dump sites. This practice exposes them to toxins and infectious diseases

\subsection{Solid waste recycling}

Recycling is a series of activities that includes collection of recyclables materials that would otherwise be considered waste, sorting and processing recyclables into raw materials such as fibers, and manufacturing raw materials into new product. It was observed that $85.96 \%, 98.18 \%$ and $87.37 \%$ of residents in zone I, zone II and zone III respectively agreed that waste can be recycled. The result shows that the residents have knowledge of converting wastes to other useful items. Composition of solid waste in Makurdi urban area (Table 2) indicated that $57.5 \%, 53.7 \%$ and $36.4 \%$ of solid waste composition in LoDA (zone I), MeDA (zone II) and HiDA (zone III) respectively are putresceables. This is an indication that effort could be channeled towards composting.

The percentages of plastic, paper, metals, glass and textile are relatively low. However, this may not warrant sitting of material recovery facility in the metropolis. Manual sorting of these recyclable material should be encouraged,

\section{Conclusion}

An environment with a high standard of sanitation that is both clean and beautiful has a greater influence on our psychological, emotional and social well being. It enhances public health and our quality of living (Agbede and Ajagbe [8]). Solid waste management in Makurdi metropolis no doubt is a critical issue. The war against inefficient and ineffective SWM must be declared and won. This became imperative if good quality of life and sustainable environment must be maintained.

The current scenario of solid waste management in Makurdi metropolis is to collect Solid Waste (without sorting) from the metropolis and dump it at the 
dump site. This system is barbaric and unacceptable socially and environmentally. The current solid waste management paradigm must shift to a socially acceptable, economically viable and environmentally-friendly solid waste reduction, reuse and recycling. A major step towards an effective solid waste management is to raise public awareness on the importance of creating a healthy environment as well as mechanism of controlling generation of solid waste at source and providing an alternative disposal means (Coker et al. [9]).

$39.97 \%$ of urban wastes generated in Makurdi metropolis are organic in nature. The best use for these wastes is to utilize it in biogas production. According to Sridhar et al. [10], "Biogas is essentially a rural technology. However, it has the ability to be adapted for urban and peri-urban areas. Classical plants utilized human excreta and animal waste. The future lies in utilizing urban waste particularly food waste. Another of biogas technology which was not adequately considered in developing countries is tapping from city refuse"

Any activities that reduce the amount of waste produced will definitely reduce the cost of waste disposal. That is why solid waste reduction, reuse and recycling are highly beneficial to a metropolis such as Makurdi in a developing country where it is estimated that nearly $10 \%$ of the population live below national poverty line (World Bank [2]). There are however important environmentally sound lessons that can be learned from the poor with respect to both the reduction of waste and its reuse [11]. It is a common practice in Makurdi metropolis for lower income people to buy used clothes for reuse and make use of use plastic material, paper and tin cans.

The study has shown that above $72 \%$ of the respondents have the knowledge that solid waste can be reduced, reused and recycled. However, it should be noted that having knowledge that waste can be reduced from source does not mean that they have knowledge of how to reduce waste from source. For the fact that residents know that waste can be reused does not mean that they are reusing wastes. There is a need for the residents to be educated or informed on how solid waste can reduced from source

The residents need to be informed that one vital way of dealing with issue of reducing waste is not to generate it at all. Before buying anything at all, questions should be asked: Do I just want this thing or I really need it? Can I put pride aside and borrow it (reuse)? Can I rent it? Can I buy it? Honest answers to these questions will lead to the best step to take that will be socially acceptable, economically viable and environmentally friendly. Any activities that reduce the amount of waste produced reduce the cost of waste disposal, the amount of raw material needed, amount of pollution generated and the better for our dear environment.

Recycling on small or large scale requires a substantial capital which is neither readily assessable nor available. This is an area where government and private investors have to be involved. Government need to put uninterrupted electricity supply in place as basic ingredient for small medium and large scale industry. Market for recyclable products should also be strengthened. The role of women in solid waste management at household level should not be overlooked. In the traditional Nigeria societies, domestic activities such as 
provision of water for general household use, maintaining a clean environment in the house by disposing household wastes and maintaining sanitation facilities, have been delegated to the women of the community (Coker et al. [12]). However, sustainability of solid waste management activities such as waste reduction, reuse and recycle without paying due attention to women's role can hardly achieve its objectives. A survey by the United Nation's Children's Emergency Fund (UNICEF [13]) has revealed that developmental projects which did not involve women failed to realized their full objectives.

\section{References}

[1] Adewumi, I.K., Ogedengbe, M.O., Adepetu, J.A. and Aina, P.O. Aerobic Compositing of Municipal Solid Waste and Poultry Manure. Journal of Applied Science and Research, 1(3), pp. 292-297, 2005.

[2] World Bank, http://www.worldbank.org/afr/findings/english/find62.htm

[3] Wikipedia, http://wikipedia.org/wiki/Benue State

[4] National Population Census. Federal Republic of Nigeria Official Gazette. No. 4. Lagos $19^{\text {th }}$ January, 2007 Vol.94, 2006.

[5] Sha'Ato, R., Aboho. S.Y., Oketunde, F.O., Eneji, I.S., Unazi, G. and Agwa, S. Survey of Solid Generation and Composition in a Rapidly Growing Urban Area in Central Nigeria. Waste Management, 27, pp. 352-358, 2007.

[6] Sangodoyin, A.Y. and Coker, A.O. Case Study Evaluation of Health-Care Solid Waste and pollution Aspects in Ibadan, Nigeria. Journal of Applied Science, Engineering and Technology, 5(1\&2), pp. 27-32, 2005.

[7] Tyler, G. Miller, Jr., Environmental Science, Eleventh Edition, Thomson Brooks Core, pp.394, 2006.

[8] Agbede, O.A. and Ajagbe W.O. Solid Waste in South Western Nigeria. International Journal of Environmental Issues, 2(1 \&2), pp. 92-100, 2004.

[9] Coker, A.O., Awopetu, M. S. and Awopetu, R.G. Assessment of Resident's Awareness, Attitude and Participation in Solid Waste Management in Makurdi Metropolis, Nigeria. International Journal of Engineering, 4(1), pp. 39-45, 2010.

[10] Sridhar, M.K.C., Coker, A.O., Aikhomu, S.E., Ifedayo, A.O. and Itodo, I.P. Biogas Production from Organic Wastes: Nigeria Effort. The Nigerian Field, 68, pp. 112-124, 2003.

[11] Toolkit on Social Assessment and Public Participation in Municipal Solid Waste; Urban Environment Thematic group. http://www.worldbank.org/ urban/uswm/socialassessmenttoolkit.pdf

[12] Coker, A.O., Olowokere, A.O. and Sridhar, M.K.C., Gender Involvement in Community Waste Management in Urban Nigeria. Proc. of the $27^{\text {th }}$ Conf. On Water, Engineering and Development, Loughborough University, UK, pp. 223-226. 2001.

[13] UNICEF,http://www.dnr.crnell.edu/saw44/NTRES331\%5CProducts\%5CS pring $\% 202004 \% 5$ CPapers $\% 5$ CSolidWasteManagement.pdf 